Kolozsvár, 2003. március 21-22.

\section{KERÁMIA TÜKRÖSÍTÉSE ELID KÖSZÖRÜLŐ ELJÁRÁSSAL}

\author{
László Zoltán
}

\section{Summary}

About machining process the cumulative demands need, it is necessary to produce small surface roughness and less measured form error. To realize these parameters we need better position accuracy. In the practice widespread the ultra precision lathe machine, which is convention to complement with an another ultra precision equipment, also the grinding or polishing. The purpose of this article to develop the ELID process specialities, and how is possible to implement.

\section{Összefoglalás}

A megmunkálással szemben támasztott növekedő igények szükségessé teszik a kis felületi érdesség és a jó alakpontosság elérését. Mindezen paraméterek biztosításához szükséges a nagy pozicionálási pontosság. A gyakorlatba leginkább elterjedt az ultrapreciziós eszterga, amely berendezést gyakran ki szokták egészíteni más ultrapreciziós berendezéssel, mint a köszörülés vagy a polírozás. Ezen tanulmány témája feltárni az ELID megmunkálás, sajátosságait és megvizsgálni miként illeszthető egy ultrapreciziós esztergához.

\section{Az ELID köszörülés elve}

[1] Az eljárás leginkább a hagyományos köszörülésre hasonlít, mely során a köszörúkorong leválasztja az alkatrészről a kívánt ráhagyást. A korong forgácsolóképességét és geometriáját egy beépített elektrokémiai eljárással folyamatosan szabályozzuk. A köszörőkorong mikronnagyságú szuperkemény szemcséket tartalmaz, amelyek be vannak ágyazva az elektromosan vezető kötőanyagba. A koronghoz közel helyezkedik el az elektróda, mely geometriai kialkítását tekintve minél nagyobb felületen állandó távolságra van a korong felültétől. A korongot és az elektródát egyenfeszültségre kapcsoljuk, mégpedig úgy, hogy a korongra az anód $(+)$, az elektródára a katód (-) kerül. A két fél közé elektrolit folyadékot engednek, mely hatására megindul az elektrolizis, azaz az áramot vezető kötőanyag kezd levállni. A folyamat során a felszínre kerülő fém oxidálódik, mely réteg keménysége elmarad az alapanyagétól. Amikor pedig elkezdődik a forgácsolás, a szerszámról leválik a kis szilárdságú oxidált réteg, és a szemcsék képesek lesznek forgácsolni. Ez után már csak folyamatosan szinten kell tartani az elizálást (1 ábra.). 


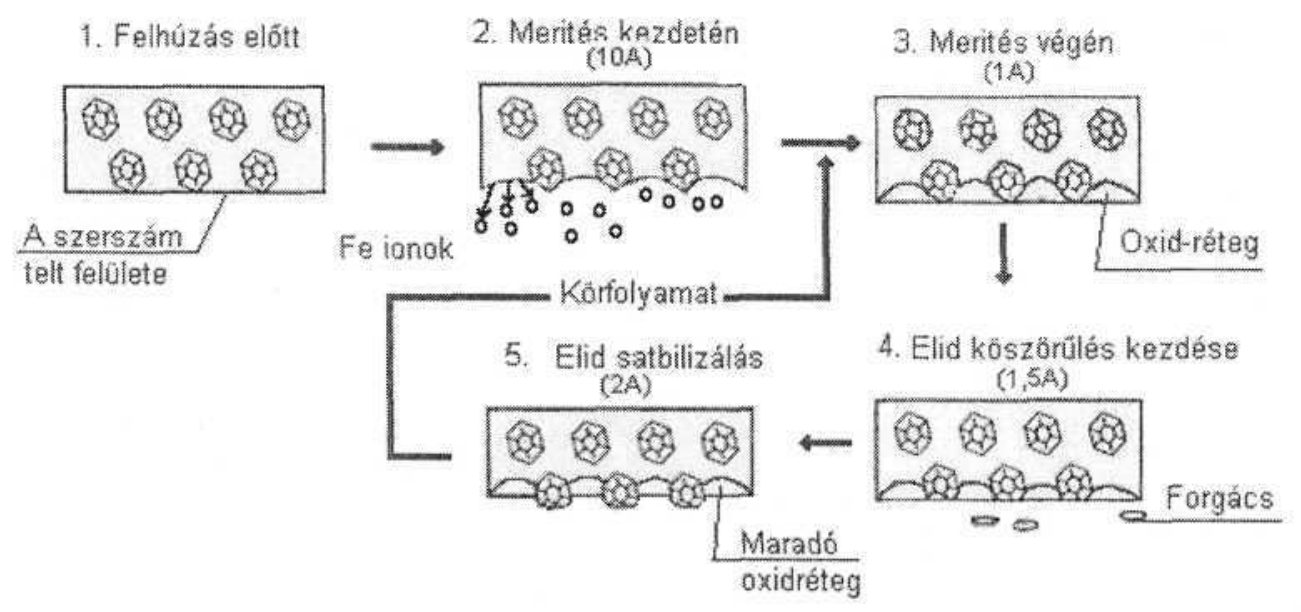

1. ábra ELID

A köszörüléshez hasonlóan itt is meg lehet munkálni mind külső, mind belső felületeket ( 2 ábra).

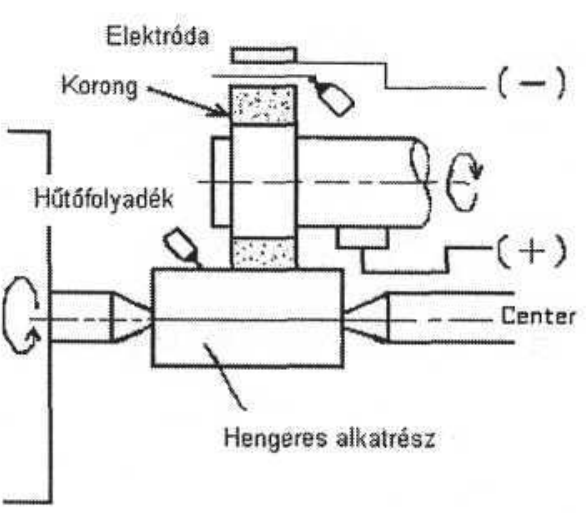

2. a ábra ELID külső felületre

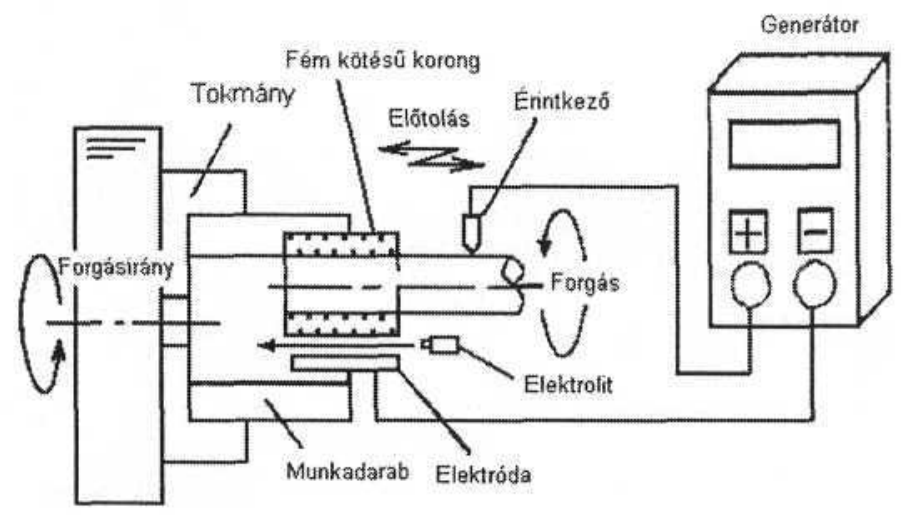

2. b ábra ELID belső felületre

Van olyan eset, amikor nem kívánjuk folyamatosan a korong szabályozását, eben az esetben szakaszossá válhat a folyamat. Legyen ennek oka, hogy nem fér be a furatba a korong is és az elektróda is, vagy bármi más, ebben az esetben a szerszám (korong) „felújítását,, szakaszosan tehetjük meg (3 ábra).

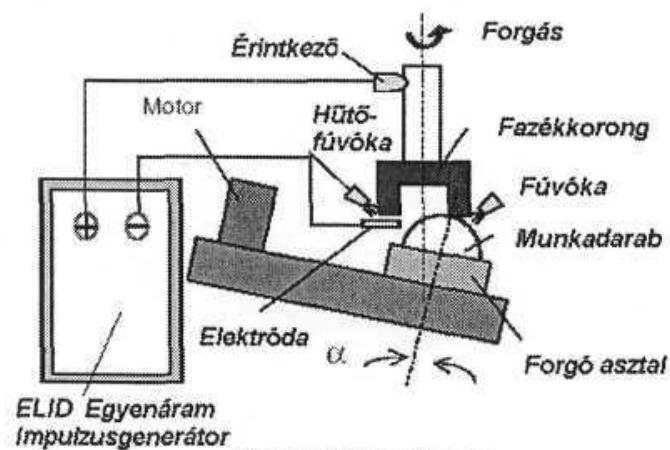

Folyamatos üzem

3. a ábra Folyamatos ELID

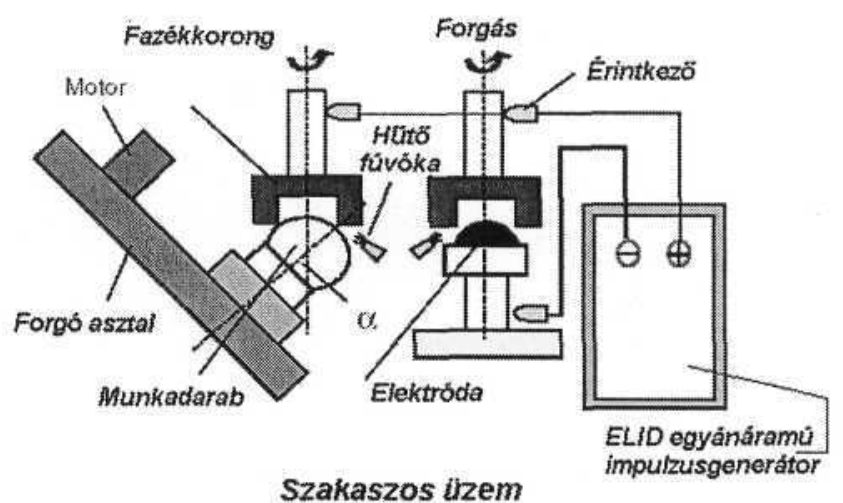

3. b ábra Szakaszos ELID

A köszörüszerszám kötőanyaga lehet öntöttvas, bronz vagy kobalt. Különleges esetben gyanta-fém keveréke.

A szemcse anyaga köbös bornitrid $(\mathrm{CBN})$ vagy gyémánt $(\mathrm{D})$. A szemcseméret általános használat esetén 60-30000 szitaszámú. Különleges gyanta-fém hibridkötéssel ultra-finom akár 3 mo-s FEPA számú abraziv porból is készülhet a szerszám (4 ábra). 


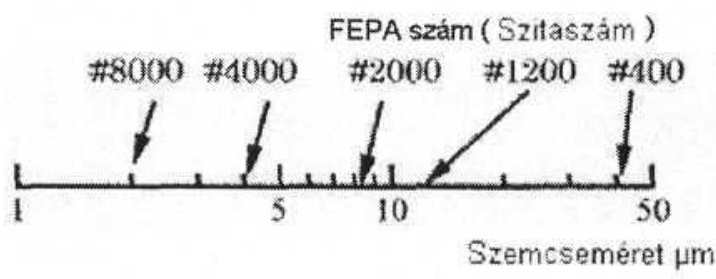

4 ábra Szemcseméret-szitaszám.

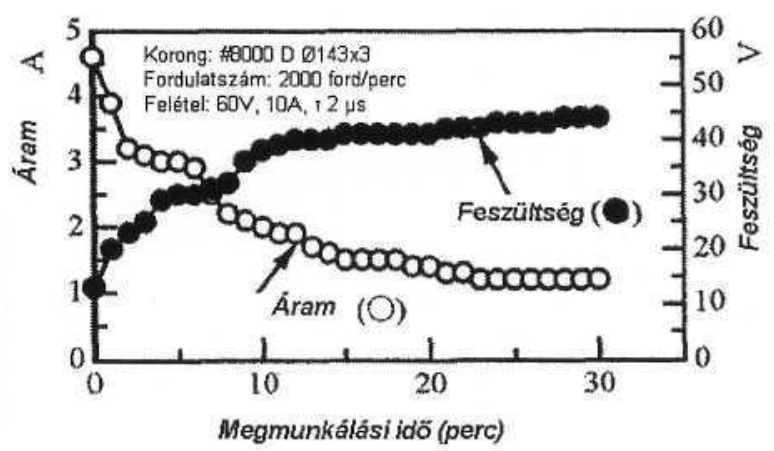

5. ábra Teljesítményszükséglet

A generátor nagyfrekvenciás egyenáramot biztosít, felharmonikusok és zajok kiküszöbölésével. A [2] irodalmi kísérlet $\mathrm{Gd}_{2} \mathrm{SiO}_{5}$ típusú kerámia megmunkálásakor fellépő áram és feszültségigény (5 ábra).

Az elektróda anyaga jól vezeti az áramot, geometriai kialakítása, pedig olyan, hogy a korongot rövid hosszon követi és a tőle való távolsága állandó.

A korong és az elektróda közötti térben az ELID folyadék található. Ez a víz alapú folyadék a felületeket nedvesen tartja, a benne lévő vegyületek segítségével pedig az elektrolízis folyamatossága áram jelenlétében biztosítható. Általában 2\%-os hígított folyadék, vagy pedig $\mathrm{NaCl}$ (konyhasó) vizes oldata.

\section{Az ELID paramétereinek változtathatósága}

Az ELID-del történő megmunkálással az a célunk, hogy polírozott (tükrös) felületi minőséget állítsunk elő. Itt elsősorban a felületi érdesség csökkentése a cél, de az eljárás sajátosságából adódóan lehetőség van alakpontosság javítására is.

A [2] 6a. ábrából látszik, hogy a szemcseméret csökkentésével jobb felületi minőség állítható elő.

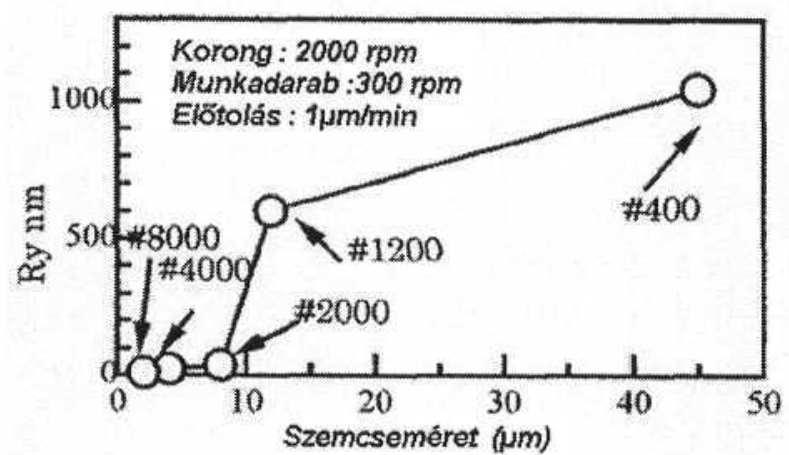

6a. ábra Szemcseméret-Ry

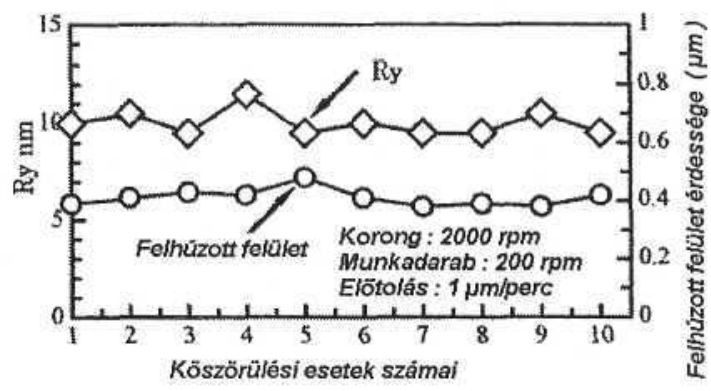

6b. ábra Felületi minőségarány

A \#8000-es szemcséjü korong felhúzott felületének érdessége hatással van az elkészült felület minőségére, de az ábra szerint jól látható hogy az új felület rendkívül kis felületi érdességgel rendelkezik (6b ábra).

Az [3] 7a és a 7b ábra mutatja egy tengelyszimmetrikus SIC tükör megmunkálás ELID köszörüléssel. A megmunkálás után a profil megmérésével ki lehet számolni az eltérés profilját, ez a hiba, pedig az NC vezérléssel kompenzálható. 


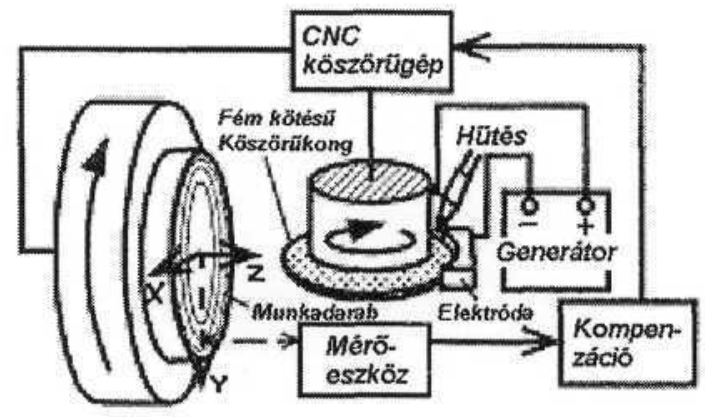

7a. ábra ELID-CNC

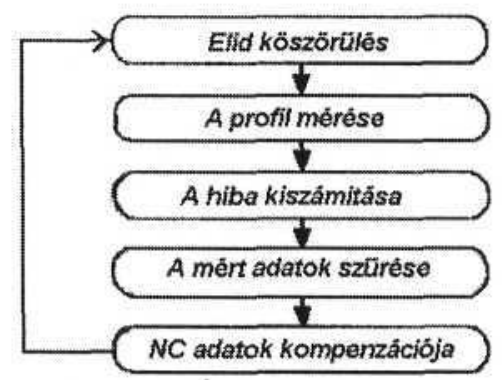

7b. ábra Alakhiba-kompenzáció

Az NC adat és az alakprofil adat NC pontját jelöljük $z x^{i}$ és $e x^{i}$ az i-edik köszörülés során. Az ( $\mathrm{i}+1$ )-k NC adat értéke: $\quad z x^{(i+1)}=z x^{(i)}-K \cdot e x^{(i)}$

Az (i+1 )-dik adat a következő formulával fejezhető ki:

$$
z x^{(i+1)}=\sum_{i}\left(z x^{(i)}-e x^{(i)}\right) / n
$$

ahol $\mathrm{n}$ a referencia adatok száma

Például, ha az utolsó két páros adatot vesszük, akkor a következőképpen néz ki:

$$
z x^{(i+1)}=\left\{\left(z x^{(i)}-e x^{(i)}\right)+\left(z x^{(i-1)}-e x^{(i-1)}\right)\right\} / 2
$$

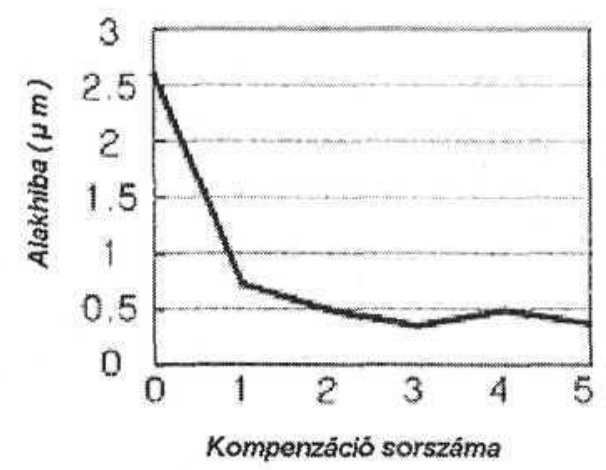

8. ábra Kompenzáció

Több páros adatainak figyelembe vétele azt eredményezi, hogy egyre kisebb befolyásuk van. A felhasznált adatok száma befolyásolja a adatok szórásának a fokát és az alakpontosság konvergenciájának a sebességét. A kompenzáció nélküli alakhiba $2,6 \mu \mathrm{m}$ az ötödik iterációra már $0,38 \mu \mathrm{m}$ alá csökkent (8 ábra.).

\section{Következtetés}

A fent bemutatott szakirodalmi példákból egyértelműen kitűnik, hogy egy nagyon hatékony technológia áll a rendelkezésünkre, amely egy meglévő GNC esztergához implementálva különlegesen magas felületi minőségi követelmények teljesítésére is alkalmas.

\section{Irodalom}

1. http://www.fujidie.co.Jp/e/seihin/elid/index.html

2. Characteristics of ELID grinding of Gd2SiO5 by cast-iron bonded diamond wheel Nobuhide Itoh,. 1 Hitoshi Ohmori,.2 Shinya Morita,.2 Hiroyuki Ishibashi,.3 Chikara Uetake,.4 and Toshio Kasai.5 RIKEN Review No. 34 (April, 2001): Focused on Advances on Micro-mechanical Fabrication Techniques

3. Ultraprecision Form Control of Aspheric Mirror with ELID Grinding Sei MORIYASU1), Hitoshi 0HM0RI1), Jun-ichi KATO2), Hajime KOGA3)and Masaru 0HMAE3)

\section{LÁSZLÓ Zoltán, PhD hallgató, okl. gépészmérnök}

Budapesti Múszaki és Gazdaságtudományi Egyetem Gépgyártástechnológia Tsz.

1111 Budapest Egry J. u 1. E ép. II.

Tel.: (+36) 1463 2640; Fax: (+36) 14633176 ; E-mail: laszlo@manuf.bme.hu 